\title{
Fish-on-a-chip: a sensitive detection microfluidic system for alzheimer's disease
}

\author{
Jasmine P Devadhasan ${ }^{1}$, Sanghyo Kim ${ }^{1 *}$ and Jeongho $\mathrm{An}^{2^{*}}$
}

\begin{abstract}
Microfluidics has become an important tool in diagnosing many diseases, including neurological and genetic disorders. Alzheimer's disease (AD) is a neurodegenerative disease that irreversibly and progressively destroys memory, language ability, and thinking skills. Commonly, detection of AD is expensive and complex. Fluorescence in situ hybridization (FISH)-based microfluidic chip platform is capable of diagnosing AD at an early stage and they are effective tools for the diagnosis with low cost, high speed, and high sensitivity. In this review, we tried to provide basic information on the diagnosis of AD via FISH-based microfluidics. Different sample preparations using a microfluidic chip for diagnosis of AD are highlighted. Moreover, rapid innovations in nanotechnology for diagnosis are explained. This review will provide information on dynamic quantification methods for the diagnosis and treatment of AD. The knowledge provided in this review will help develop new integration diagnostic techniques based on FISH and microfluidics.
\end{abstract}

Keywords: Fluorescence in situ hybridization (FISH), Microfluidic chip, Alzheimer's disease (AD), Nanoparticles, Molecular probes

\section{Introduction}

Fluorescence in situ hybridization (FISH) was developed during the 1980s, for the detection of specific nucleic acid sequences and cytogenetical analysis [1,2]. Further, FISH has replaced conventional methods such as radioisotope probe labeling [3]. Traditional FISH techniques can safely and quantitatively detect many targets, but it is a time-consuming process [4]. Recently, FISH-based microfluidic technique was introduced and was shown to have low cost and high speed. It also offers a number of advantages such as lower amounts of sample and reagents required, less energy, less time required, disposability, compact size, computerization, and trouble-free analysis [5]. Microfluidics is useful for detecting different kinds of samples, such as microorganisms [6], biological materials (DNA, RNA) [7,8], enzymes [9], antibodies [10,11], mammalian cells [12], and biomolecular interactions, and it can also be applied to environmental monitoring, medical diagnostics, the food and

\footnotetext{
* Correspondence: samkim@kyungwon.ac.kr; jhahn1us@skku.edu ${ }^{1}$ College of Bionanotechnology, Kyungwon University, San 65, BokjeongDong, Sujeong-Gu, Seongnam-Si, Gyeonggi-Do 461-701, Republic of Korea ${ }^{2}$ Department of Polymer Science \& Engineering, SungKyunKwan University, Suwon, Gyeonggi-do 440-146, South Korea

Full list of author information is available at the end of the article
}

agricultural industries [6,13-15], and detection of genetic disorders [5]. Such as the well known genetic diseases are cardiovascular problems, diabetes, cancer, arthritis and Alzheimer's diseases (AD) [16]. Inheritance of AD is complex $[17,18]$ and involves language breakdown, mental confusion, and memory loss [19]. AD was first described by German psychiatrist Alois Alzheimer in 1906 [20]. It is a common and complex disease that has various environmental and genetic aspects $[21,22]$. One recent report found that 1 in 85 people worldwide will have AD by 2050 [23].

Amyloid precursor protein (APP), presenilin 1 (PS-1), and presenilin 2 (PS-2) and sporadic forms genes such as apolipoprotein $E(A P O E)$ increase the risk for $\mathrm{AD}$ later in life [24]. Therefore, early genetic-based diagnosis is very important for managing AD. FISH-based microfluidic analyses are highly suitable for the detection of single nucleotide polymorphisms (SNP) [5]. Hence, biomarkers and molecular probes are important to detecting $\mathrm{AD}$ at an early stage [25]

Alternatively, peptide nucleic acid (PNA) probes can be used for diagnosis instead of DNA probes or as complementary probes to DNA. They exactly mimic DNA probes and therefore one of the most powerful tools for 
molecular biology and medical diagnostic analysis. PNA can bind to complementary strand of DNA and RNA sequences with high affinity and high specificity [26-28]. PNA-based FISH analyses are used for quantitative telomere analysis using fluorescent-labeled PNA probes [26]. Labeling analysis reveals human telomeric repeat sequences and also can accurately estimate telomere lengths [29]. PNA can also form a triplex with the target double-stranded DNA [30]. Apart from this, duplex invasion, double duplex invasion, and triplex invasion binding are also possible [26]. Perhaps the detection of DNA hybridization by electrochemical method was high compassion, cheaper with advantage of microfabrication technology [31] and using PNA probes for hybridization is equally possible in this technology [32]. Moreover, this PNA shows high affinity with DNA sequences, antisense and antigen agents, biosensors, and molecular probes [30].

This review attempted to summarize the requirements for integrating FISH techniques with microfluidic technology for AD diagnosis. Since, AD detection is possible at an early stage, which is an easy and cheaper detection method. A detailed discussion concerning the detection of $\mathrm{AD}$ is carried out.

\section{FISH-Based Detection of Chromosomal Abnormalities}

Though the numbers of automated scanning systems are commercially available, the visual based detection methods are most important for confirmation of results $[33,34]$. FISH is a great system for identifying chromosomal abnormalities. It can be applied to genetic mapping and diagnosis of novel oncogenes, solid tumors, and various cytogenetic disorders. It also has achieved universal acceptance as a clinical laboratory tool $[35,36]$. Most importantly, microchip-based FISH techniques can reduce labor time and cost [37]. The human chromosome has been analyzed biochemically and structurally for cytogenetic investigations and diagnostics. FISH technique can also be used to analyze chromosomal details and localize a specific gene, and it is important to develop the fluorescence microscopy [38].

Initially, AD was diagnosed by enzyme-linked immunoassays (ELISA), which is further extended to develop nanoparticle-based bio barcode amplification analysis. Bio barcode assay (BCA) is more than 1 million times more sensitive compared to ELISA, and it uses amyloid $\beta$ derived diffusible ligands (ADDLs) as a marker. BCA assay can also be used to diagnose AD with about $85 \%$ accuracy, due to the high amount of ADDLs present in the cerebrospinal fluid (CSF). However, the drawback of obtaining the CSF sample from the spinal cords [39]. To overcome this difficulty, researchers are trying to design a test that uses blood and urine samples instead.
Recently, Ivan and colleagues reported that human brain diseases such as AD, which are present in the human brain and are associated with chromosomal disorders [40-42]. In this research, chromosome 21 aneuploidy in lymphocytes and fibroblasts cells of AD patients was observed using FISH techniques [43-45]. In this study, three kinds of DNA probes were used, including chromosome enumeration probes [46-48] micro detection probes [49], and five color probes [40,33]. These probes were used along with multicolor FISH techniques. Using this technique, evaluated more than 480,000 neural cells $[40,50,51]$. FISH analyses on five different chromosomes and 7000 nuclei from seven brain tissue samples were carried out at the same time. The signals were captured using a CCD camera by the quantitative FISH method (cohu, 4910 series, cohu inc., San Deigo, CA) [40]. Several proteins were identified as risk factors of $\mathrm{AD}$, including PS-I, APOE $\varepsilon 4$, and amyloid $\beta$ peptide. According to Takako et al., the PS-I gene is found on chromosome 14q24.3. This single 14q24.3 locus can be detected by FISH [52-54]. Amyloid $\beta$ peptide is a risk factor for AD and can be found in the urine of AD patients. When analyzed by Western blotting, 0.003 to $1.11 \mathrm{ng}$ in $1 \mathrm{ml}$ of amyloid $\beta$ peptide was obtained from a urine sample [55]. (Table 1) Summarized the other biomarkers of AD and their sample sources [56-65].

Other research has proved that FISH is an effective detection technology for AD. Generally, premature centromere separation (PCD) is associated with numerous human diseases [66]. PCD was analyzed using peripheral blood lymphocytes samples of AD patients on chromosome 18. The comparative analysis was carried using elderly samples (as control). FISH has proven that the frequency of PCD is very high on chromosome 18 and that this disease is associated with aneuploidy [67].

Table 1 List of biomarkers for Alzheimer disease and their sample source

\begin{tabular}{llll}
\hline Factor & $\begin{array}{l}\text { Sample } \\
\text { Source }\end{array}$ & Biomarkers & Ref \\
\hline $\begin{array}{llll}\text { Histopathological } \\
\text { factors }\end{array}$ & Urine, Blood & $\begin{array}{l}\text { Amyloid beta } \\
\text { peptide }\end{array}$ & {$[55,56]$} \\
& CSF & $\begin{array}{l}\text { Tau protein } \\
\text { Phosphorylated } \\
\text { tau }\end{array}$ & {$[57]$} \\
& CSF & {$[58]$} \\
\hline Genetic factor & Blood,saliva & APOE & {$[59,60]$} \\
& CSF, blood, & APP & {$[61,62,60]$} \\
& saliva & PS-1 & {$[63]$} \\
& Blood & PS-2 & {$[63]$} \\
\hline Synaptic pathological & CSF & ADDL & {$[39]$} \\
& & & \\
\hline Oactor & CSF & Somatostatin & {$[64]$} \\
& Blood & Metal ions & {$[65]$} \\
\hline
\end{tabular}


As mentioned before, PCD is one of the reasons for causing $\mathrm{AD}$, hence the blood lymphocytes in metaphase stage have used for the cytogenetic analysis. Since individuals with $\mathrm{AD}$ contain a high amount of PCD at metaphase stage, disease detection in the micronucleus (MN) of blood lymphocytes can be carried out using FISH. For this reason the chromosome pancentromeric DNA probes has been used $[38,68]$. FISH technique based results and records have been established to develop this research forth.

FISH is a sensitive technique for detecting cytogenetical disorders, but it also has some drawbacks. FISH analysis requires an efficient and experienced staff as well as a large amount of expensive probes for the experiment (Approximately $\$ 90$ per slide). Chip-based analysis requires 0.5 to $1 \mu \mathrm{l}$ of probes, whereas conventional FISH method requires $10 \mu \mathrm{l}$ of probes. Microfluidic chip-based FISH techniques reduce the cost by 10 to 20 -fold $[37,38,69,70]$ as some possible probes impede the high cost effect.

As discussed before, PNA probes used in molecular diagnostic and FISH-based detection [71] can be used to diagnose neurodegenerative dementia, chromosomal disorders such as Parkinson's, frontotemporal dementia (associated with chromosome 17), AD [72], and genomic mutation or labeling of chromosomes [26]. PNA probes are used for in situ hybridization to recognize human chromosomes $1,2,7,9,11,17$, and 18 in metaphase and interphase stage nuclei $[73,74]$. Multicolor PNA probes are used for the samples such as lymphocytes, aminocytes, and fibroblasts $[54,75]$. Based on the above literature review, AD at an early stage can be detected on chromosome 18 [67], chromosome 17 [72], and lymphocytes [68] by the FISH method. PNA oligomers can be integrated with a micro total analysis system such as microarray and automatic construction of PNA records array [76,77]. Furthermore, DNA/DNA hybridization, PNA/DNA hybridization, and antigen-antibody interaction for proteins like APP is possible using a microfluidic chip [78].

\section{Connection of Microfluidic Chip for Detection of Alzheimer's Disease}

Highly qualified and efficient technicians spend several hours performing conventional FISH protocol using centromeric probes; it takes a minimum of 2-3 hours to complete the process. However, anyone can manage microfluidic chip-based FISH techniques, as only a few minutes are required to complete this procedure. A FISH-based microfluidic chip device can analyze thousands of genes or thousands of patient samples at a single time, and a technician only needs to spend a few minutes [69]. Many types of analyzing materials are used to study the nervous system [75]. Microfluidic chips are one of the most useful devices for detecting neurodegenerative diseases such as AD. For AD, early identification is important as this type of neurodegenerative disease has dangerous effects in later life [25]. This can be combined with a micro electroporation chip to detect other genetic disorders such as Huntington's disease, autosomal dominant Parkinson's disease, and charcot-marie-tooth disease [79-81]

Moreover, microfluidic chip is one of the most effective tools for disease detection; especially for genetic based diagnoses and other biomedical applications [82-88]. This microfluidic technique has evolved from Micro Electro Mechanical Systems (MEMS). The MEMS eliminated other critical biophysical, chemical and biological analysis [89]. The main aim of this microfluidic system is miniaturization. The major constituent of the microfluidic chip is fabricating materials and controlling the fluid flow [90]. The microfluidic chip accommodates the test fluids and chemicals within the channel to carry out the experiments, where the channel size ranges from $10-100 \mu \mathrm{m}$ or more in width. Basic principles of microfluidics flow through the channel could be characterized by the Reynolds Number, This is described as $\operatorname{Re}=\rho v \mathrm{~L} / \mu$, where $\mathrm{L}$ is the most relevant length scale, $\mu$ is the fluid viscosity, $\rho$ is the fluid density and $v$ is the average velocity of the flow [91]. There are two common processes for fluid motion: laminar flow and electrokinetic flow. One of the basic laws of the laminar flow is pressure and diffusion to distribution of the molecules transported within the channel. The electrokinetic flow needs electrohydrodynamic force between the inlet and outlet port [92]. The microfluidic device control the movement of fluids via force or electrical energy and integrated optical system finds the solutions of the particular experiment. Different kinds of materials are used to make microfluidic chips and it is useful for different kinds of biochemical analyses, particularly polydimethylsiloxane (PDMS) chips [85,87], paper based chips, and thermoplastic chips, which are very cheap. It also helpful in making inexpensive disposable chip and to avoid the cross contamination of biological samples [93-95]. Recently, advanced techniques incorporated with microfluidic chips were developed for optical, electrical, and mechanical sensing. This can be achieved by connecting or attaching a CCD and CMOS sensor to the microfluidic chip. FISH based chip method shows high sensitivity even with a low amount of sample [96].

Microarray and BCA are major detection tools for biological analysis. Microarrays are a one of the micro total analysis system ( $\mu$ TAS) and it is a direct method for the detection of single nucleotide polymorphisms (SNPs). However, microarrays require an expensive device for analysis and require a long incubation period [97]. The 
sample should be amplified by polymerase chain reaction (PCR). If the sample concentration is very low, the immobilized sample should be fixed on a glass slide using a microarray spotting machine [98]. It needs a special scanner to analyze the microarray chip. Compared to microarrays, microfluidic chips used for SNP detection require less time and are more sensitive even with a small amount of sample [97]. Ultra high-throughput microfluidic chips are more reliable for disease diagnosis as it focuses on SNP analysis for AD detection and can lead to the development of drugs for SNP. Microfluidic chips have the ability to perform hundreds of reactions and can synthesis up to 10,000 compounds per chip [99].

BCA is a sensitive analytical method for detection of $\mathrm{AD}$ and other diseases. It can also be used as a diseasemonitoring device and for the analysis of disease markers $[39,100]$. Moreover, BCA system used to detect amyloid $\beta$ protein, which is a hallmark of AD [39]. Microfluidic chips have replaced many laboratory tools, including BCA, due to its portability, automation, and simplicity. Hence, BCA continues to be the next stage of development for surface-immobilized BCA $[39,100,101]$, but its working format resembles a microfluidic chip. Integrated microfluidic barcode chips increase the sensitivity of the detection [97,102]. BCA proved the several considerable and new analytical potentialities, though it is not even in its most favorable form. To analyze the target DNA sequence it needs three different kinds of oligonucleotides like magnetic particle capture sequence, universal sequence and barcode capture strand, it is synthetically demanding and expensive. Hybridization of barcode DNA with support strands on Au-NP surface is extremely difficult to attain $100 \%$ loading consistently. Skilled person are required for operating this system and should follow several safety procedures when using human samples [103]. Also they have limitation to use the different colors of fluorescent labels in BCA $[95,104]$ and it needs reader like verigene ID to find out the data [47]. But the microfluidic chip has designed with an encapsulated BCA, surface immobilized BCA. This single device is simple, inexpensive, and can be used in many applications such as chemical reactors, sensors, and more [100,102].

FISH is carried out as an automatic method on a microfluidic chip, as illustrated in Figure 1. Sieben et al., used a microfluidic chip which is useful for distinguishing the chromosomal defects from PBMC cells. The cell suspension were mixed with PBS and introduced in the microchannel by capillary force. This chip should be heated to improve the cell attachment on the channel surface. These cells were treated with proteinase K. The Proteinase $\mathrm{K}$ is allowed to digest the cells, and also it is helpful to enter the respective DNA probes with

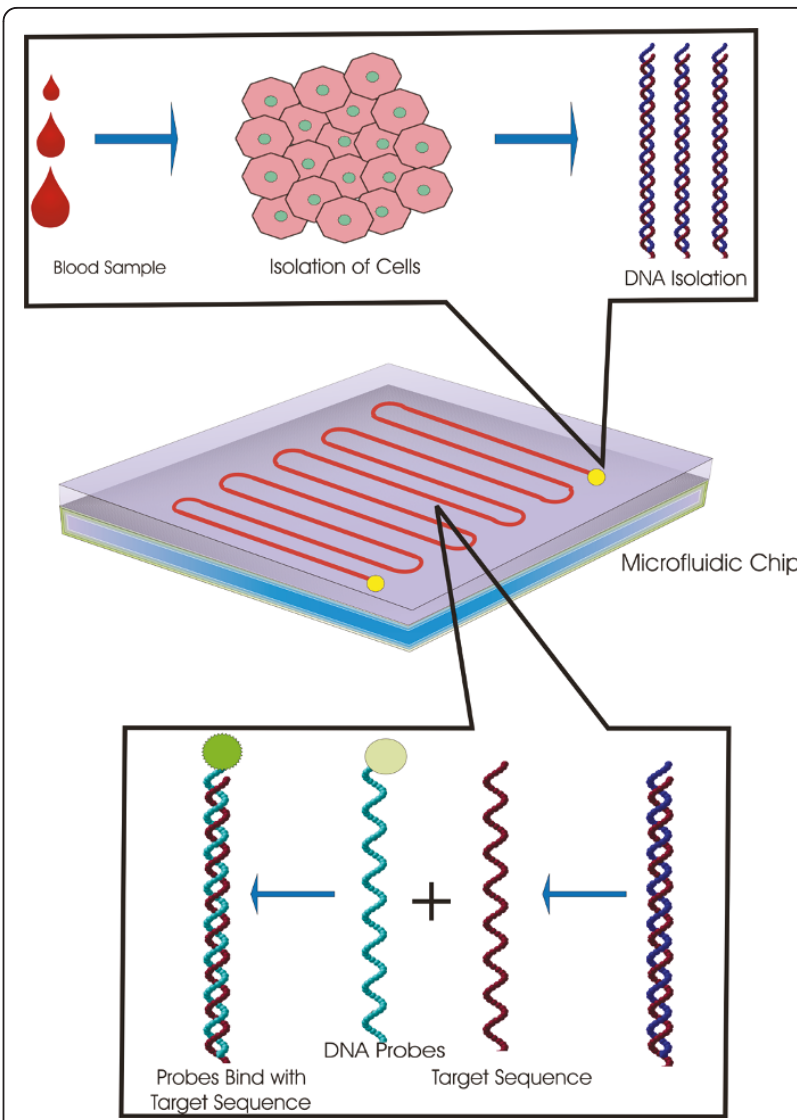

Figure 1 Analysis of blood sample using FISH based on microfluidic chip. Blood samples introduced into the microfluidic chip by capillary force and cells were attached on the channel surface by heating the microfluidic chip. Then Proteinase $\mathrm{K}$ introduced into the chip to digest the cells, followed by increasing the temperature of microfluidic chip for few sec to denature the DNA, then fluorescence tagged DNA probes introduced into the chip. Complementary DNA probes hybridized with the target sequence and emit fluorescence.

fluorescence into the cells [37]. By using this technique, the detection of chromosomal defects and genetic analysis are possible within 1 hour. This is an important technique to reach the next level in this field. This method is fast, inexpensive and automated genetic screening is applied to distinguish the specific chromosomes defects (aneuploidy) and other related disorders [105]. AD is a major aneuploidy-related disorder. Peripheral blood lymphocytes [40,67] and primary fibroblast cell samples are used for the detection of AD [44]. Since, the microfluidic chip could be accomplished using the raw blood samples, which gives genetic information for many kinds of genetic disorders [99]. This microfluidic chip also can be applied to analysis of urine samples [106], the AD diagnosis could be possibly done by detecting the amyloid $\beta$ peptide, which is obtained from the urine [55]. Recent types of microfluidic chips 
reduce the reagent cost by 20 -fold and reduce the labor time by 10 -fold [99].

\section{Sample Preparation Method for Microfluidic Chip- Based Diagnosis of Alzheimer's Disease}

Sample preparation plays a major role in microfluidic chip-based analysis. Easy sample preparation helps reduce the difficulties of analysis in a short period of time. Chip-based analysis is an authentic technique like PCR, capillary electrophoresis, FISH [103], and other technologies that use nano wires [107] and nano pores [108]. In conventional methods, nucleic acid sample preparation has high labor cost and requires many steps to isolate nucleic acids from raw materials like blood, spinal fluid, saliva, and tissue. This method takes a long time to prepare the sample for biological analysis [109-111]. However, microfluidic chip-based systems avoid the difficulties of sample preparation, as it is a simple method with low cost and reagent consumption [112]. Microfluidic chip-based systems also do not require any spinning method. Chip-based sample preparation miniaturizes the entire laboratory tool in a single device with micro fabrication method and it replaces the costly equipment used for biological laboratory and clinical field [112]. This lab on chip sample preparation leads to the development of home-based self-analysis. The sample preparation includes two major steps: 1 ) cell lysis and 2) DNA, RNA extraction, as shown in Figure 2 Cell lysis is classified into four major types: 1 ) mechanical lysis 2) thermal lysis 3) chemical lysis, and 4) electrical lysis [112]. Lysis techniques aim to rupture the cell wall and release cell cytoplasm. For mechanical lysis, the cell membranes disturbed with mechanical force such as microknives [112,113], poly methylsiloxane (PDMS) membrane [114], ultra sonication [115,116], and laser beam irradiation have been used [117] to release the cytoplasm. APP can be obtained by rupturing the single membrane of CSF cells. APP has about 590680 amino acids present in the cytoplasmic tail [61]. The mismetabolism of APP increases the risk of AD. Hence, measuring the amount of APP in CSF would help detect AD [118]. Although, APP is traditionally measured by Western blotting [119], however the blotting technique does not produce accurate measurements. Therefore, it is not a truly quantitative method for APP measurement in CSF [118].

Thermal lysis is a pertinent technique for DNA and RNA isolation and involves heating the sample at $100^{\circ} \mathrm{C}$ for $40 \mathrm{sec}$ in boiling water. The technique is enough to obtain nucleic acids without any damage [120,121]. Microheating is an advanced technique that can be integrated within a microfluidic chip to isolate cell samples from blood and other sources [122]. As we discussed in Section 1, obtaining sample from the CSF is very

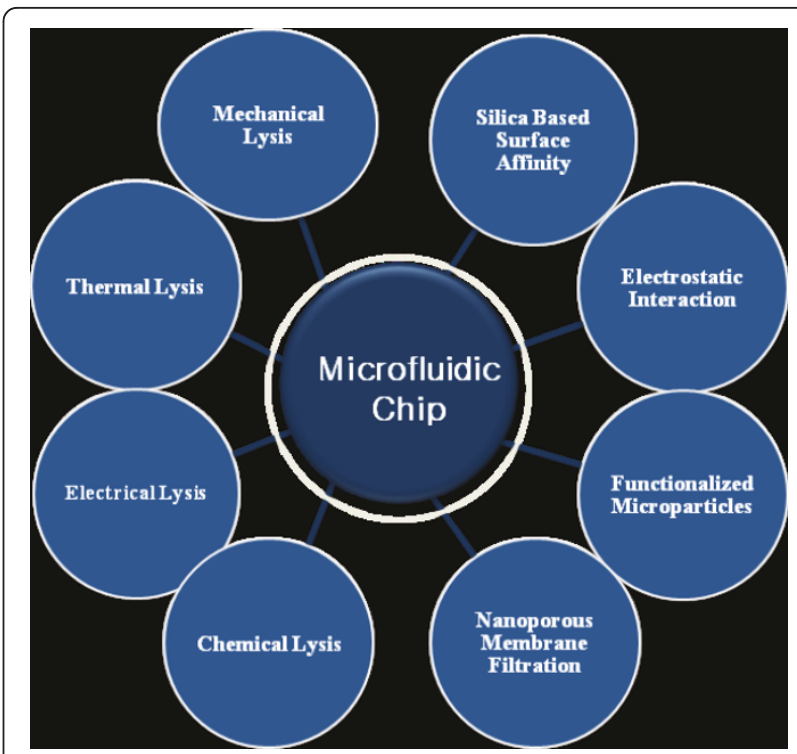

Figure 2 Sample preparation using microfluidic system: Cell lysis and Nucleic acid extraction method. Cell lysis is rupture of cell membrane and release of cell components by using cell lysis methods such as a) Mechanical lysis b) Thermal lysis c) Chemical lysis d) Electrical lysis. Nucleic acid extraction is the isolation of DNA and RNA from the cells using microfluidic chip by a)Silica-based surface affinity b) Electrostatic interaction c) Nanoporous membrane filtration d) Functionalized microparticles

difficult and painful, although very accurate. To avoid this problem, researchers have developed, blood samplebased methods for detection of AD using FISH techniques and microfluidic chips. Blood lymphocytes used for AD detection along with FISH have shown positive results [67]. Since AD is associated with chromosome 21 of human blood, the soluble form of APP can be isolated from human platelets. This isolated APP can be confirmed by immunological methods and Western blotting techniques [62].

Chemical lysis is the other important method for microfluidic-based sample preparation [112]. This can be carried out using buffers and lytic agents such as ammonium chloride [119], SDS, lysozyme, chaotropic salts, $\beta$-mercaptoethanol, and Triton-X4 that maintain protein structure and function [123-126]. Amyloid $\beta$ peptide is normally released from cells that contain small 42 residue proteins fragments. Any person with a decreased amount of amyloid $\beta$ peptides in CSF would be prone to develop $\mathrm{AD}$ [56], which has been confirmed by many studies [127]. The electrical lysis method requires electrical force to lyse the cell membrane. High intensity pulsed electric fields [PEFs] are suitable techniques for microfluidic applications, and it increases the frequency in the $\mu$ TAS analysis system $[128,129]$. The advantage of an electrical lysis system with an integrated microfluidic chip is reduced electrical power 
consumption; specifically $8.5 \mathrm{~V}$ at $10 \mathrm{kHz} \mathrm{AC}$ is enough to lyse mammalian cells with competence of $74 \%$ at low power [130]. From the above discussion, it is clear that any lysis method can be integrated into a microfluidic chip.

From the existing literature, it can be clearly understood that detection at the molecular level surely has an impact on AD diagnosis. Microfluidic chip-based DNA separation can give positive results. As we reported, microfluidic-based DNA separation can be classified into four types: 1) silica-based surface affinity, 2) electrostatic interaction, 3) nanoporous membrane filtration, and 4) functionalized microparticles [112].

Increased surface affinity and high ionic solutions are helpful in binding DNA to glass fiber and silica, due to low electrostatic repulsion and wash out the DNA with low ionic strength buffer. This is the common procedure for DNA extraction. Chaotropic salt solutions have confirmed the results of DNA adsorption and desorption with nanogram quantities of silica resins in microfabricated devices, showing $70 \%$ binding capacity in white blood cells [131]. On the other hand, hybrid architectures of microfabricated devices of silica beads and sol-gel matrix produce $\sim 90 \%$ DNA extraction within 15 min $[132,133]$. However, the drawbacks of hybrid architecture are bonding and shrinkage, which affect the DNA extraction quantity and purity of the sample. Developing tetramethylorthosilicate [TMOS]based sol-gel matrices with micro pore tools could avoid this problem, thus offering promising potential by extracting DNA from human CSF and viral DNA [134,135]. APOE (chromosome 19) from human blood leukocytes cells can also be used for AD detection. Usually, the conventional method for isolation of the $A P O E$ gene takes a long time, approximately 6-8 hours, and also requires gene amplification [59]. On the other hand, microfluidic-based DNA preparation and identification is faster and requires a smaller amount of sample. Further, AD patients contain a high amount of tau-protein in their CSF [57]. Conventional methods measure tau protein by ELISA [136], which can measure $10 \mathrm{pg} /$ $\mathrm{ml}$ of tau-protein in CSF. Using microfluidic chip-based techniques, tau protein can be measured in combination with high throughput analysis methods such as surface plamon resonance (SPR) [137].

$A P O E$ is a glycoprotein containing 299 amino acids and with a molecular weight of $34.2 \mathrm{kDa}$ [138]. Usually, APOE genes are used as biomarkers for individuals suspected of having $\mathrm{AD}$ [52]. $A P O E$ is classified into three major forms, ApoE2, ApoE3, and ApoE4, the allelic forms of which are $e 2, e 3$, and $e 4$, respectively [139]. Generally, an individual containing the $e 2$ allelic form is not at risk for AD. However, an individual containing the $e 3$ or $e 4$ allelic form is at higher risk to $\mathrm{AD}$ at early stage [52].
Integrated silicon-based microfluidic chips are useful for cell lysis and DNA extraction from whole blood [140], and they are very easy to handle [141]. Another method for DNA extraction is based on electrostatic interactions. Chitosan-coated microfluidic chips are often used for DNA extraction from whole blood and cell lysis at $\mathrm{pH}$ levels near 5 , with a rate of isolation of $68 \%$ for human genomic DNA [142]. Functionalized microparticles and magnetic beads are used for sample preparation with the aid of an integrated microfluidic chip [112]. Genetic diseases can be detected by obtaining DNA from cells in the saliva [143]. The risk for AD of APP and amyloid $\beta$ proteins isolated from saliva was analyzed by ELISA [60]. Functionalized magnetic beads were used for saliva sample preparation with the help of lysis buffer. This method could isolate and purify DNA within $10 \mathrm{~min}$ [143]. After sample preparation, the microfluidic chip can be used to identify the results.

\section{Nanomaterials Coupled With Fluorescent Probes for Diagnosis of Alzheimer'S Disease}

A pertinent technique is being developed for the optical detection of molecular disease [144]. Organic and inorganic-based nanomaterials exhibit immense potential and have excellent physicochemical visual magnetic properties, which can be easily manipulated [145-147]. Gold nanoparticles, quantum dots, and magnetic nanoparticles are used for diagnosis. Among these, gold nanoparticles play a major role in sensing applications and can be used as a multiprobe tool for visual inspection, fluorescence, Raman scattering, atomic and magnetic force, and electrical conductivity. In situ hybridization with nanoparticles can provide sensitive results. FISH coupled with nanoparticles has provided remarkable detection in both prokaryotic [148] eukaryotic cells [149]. A microfabricated device coupled with nanoparticles is 100,000 times more specific and 10 times more sensitive for DNA detection than modern genomic detection systems. The targeted disease sequence DNA presented in the sample on the chip could be bound with gold nanoparticle. Further, additional use of silver solution in the microfluidic chip can produce accurate detection with a minute amount of DNA [144]. In nanoparticle-based DNA detection, a multiple number of DNA probes could bind and detect millions of DNA sequences simultaneously. Further, it leads to the sensor based detection for the different types of biological materials $[144,150]$.

In molecular diagnosis, the nanoparticles are used as a nanoscale material due to their low toxicity, easy pairing with biomolecules, and their adaptability in various detection methods for analyses. Nanoparticle-based microfluidic analysis for biomolecules can produce the data by Fluorescence Raman Scattering or Optical 
Absorption. The low sample volumes used in microfluidic chips allow the device to concentrate and amplify signals from gold particles [151]. Biotin-labeled PNA probes immobilized on the gold surface could bind with the DNA target sequence with high affinity [152].

Nanoparticles are used in many microscale diagnostic devices such as microarrays and BCA. A microfluidic chip with nanoparticles is used for recognizing specific DNA sequences and can be confirmed by fluorescence detection. Gold nanoparticles are incorporated into the channel wall of the microfluidic chip. The DNA probes are then linked to the monolayer through thiol groups at one end and the fluorescence dye at the other end. Hybridization and detection of target genes can be carried out via in situ hybridization on the microfluidic channel. Therefore, this is a promising method for clinical diagnosis [153].

Silver nanoparticles are also useful for DNA detection applications even at a low sample concentration. An integrated PDMS microfluidic chip with high sensitivity when coupled with nanoparticles allows detection in confocal and non-confocal modes [98]. Nanoparticlebased detection of DNA hybridization and protein binding can be carried out by label-based and label-free methods. Label-based detection uses fluorescent nanoparticle labels. On the other hand, label-free detection uses sensor, SPR, surface enhance Raman scattering, and cantilever-based biosensor to detect microfluidic data in the laboratory. However, quantitative and sensitive detection is required for taking these methods to the next level of disease treatment [154]. Localized SPR of nanoparticles can be used to detect tau-protein in CSF even at picogram quantities [137]. Further, CMOS sensors used for DNA hybridization detection have been reported in micro fabricated devices [155]. These selfanalytical tools are cheap, sensitive, and user-friendly. They can also be incorporated into cell phones, digital cameras, and scanners to enumerate the results and documentation $[156,157]$.

\section{Future Perspectives}

There are many methods and devices used to detect $\mathrm{AD}$, including microarray technology, BCA, microfluidic platform, and antigen antibody-based detection. All of these techniques can be used for biological and clinical analysis. Prevention or early detection is the best solution for avoiding cytogenetic and other dangerous disorders. Patients might be unaware until harmful symptoms are felt. Usually, AD detection is a costly procedure. Hence we tried to develop a cost-effective, microchip-based AD and genetic-based diagnostic techniques for early diagnosis. Self-analyses are available for the detection of flu-like illnesses and colds. A physician can treat patients based on the data obtained from self- analysis. In the future, detecting $\mathrm{AD}$ could be made easier using FISH integrated with a microfluidic chip. This detection system would be possible at any stage of the disease. Genetic analysis is the most effective method for biological analysis and disease diagnosis using tissue, body fluids, and microbial analysis. DNAbased detection is a promising method for detecting the suppressed stage of genes. This detection method can be improved as a self-analyzing tool by using a single chip. Above all, this will be a cheaper method and the detection will be molecular level in every clinical visit. This kind of diagnosis will help reduce the number of individuals with $A D$ in the future. This integrated microfluidic chip will be used widely not only for AD treatment but also for all neurobiological diseases. Moreover, the sample collection will not be a challenging task, and detection can be possibly carried out by using blood samples and urine.

\section{Summary}

This review discussed the stages and causes of AD. Conventional detection methods of $A D$ have been using biomolecules obtained from CSF. The detection of AD using FISH techniques and microfluidic chip technology has been carried out in an appropriate manner. Detailed DNA isolation starting from cell lysis was also discussed. The role of nanomaterials in the detection of genetic disease using DNA was reviewed as well. This review envisioned FISH techniques incorporated with microfluidic devices as an innovative diagnostic tool. This method would be helpful for genetic level analysis and early stage analysis of diseases. This single chip will be useful for multiple analyses of DNA hybridization, protein analysis, and other quantitative-based analysis.

As revealed by FISH, microfluidic chip and nanoparticle-based analyses are very effective for diagnosing AD. Our aim is to join all of these effective techniques together. An integrated system would achieve biotherapy of genetic diseases. This work has increased our understanding of AD using microfluidic chips. These fusion techniques will be a common and sensitive tool for all the biological techniques.

\section{List of Abbreviations}

AD: Alzheimer's disease; ADDL: Amyloid $\beta$ derived diffusible ligands; APOE: Apolipoprotein E; APP: Amyloid precursor protein; BCA: Bio barcode assay; CSF: Cerebral spinal fluid; ELISA: Enzyme-linked immune sorbent assays; FISH: Fluorescence in situ hybridization; PCD: Premature centromere division; PNA: Peptide nucleic acid; PS-1: Presenilin 1; PS-2: Presenilin 2; SNP: Single nucleotide polymorphisms; SPR: Surface plasmon resonance Authors Contributions

JPD performed the FISH- based detection for chromosomal abnormalities and microfluidic chip- based detection for Alzheimer's Disease. SK designed the work and contributed in Sample preparation method for microfluidic chip- based diagnosis of Alzheimer's disease. JA participated in Nanomaterials coupled with fluorescent probes for diagnosis of Alzheimer's disease and performed for future perspectives. 


\section{Acknowledgements}

This work was supported by the Industrial Strategic technology development program (10035197) funded by the Ministry of Knowledge Economy (MKE, Korea) and the R\&D Program (10035638: Integrated portable genetic analysis RT-PCR microsystem for ultrafast respiratory infection disease identification) of MKE/KEIT.

\section{Author details}

'College of Bionanotechnology, Kyungwon University, San 65, BokjeongDong, Sujeong-Gu, Seongnam-Si, Gyeonggi-Do 461-701, Republic of Korea. ${ }^{2}$ Department of Polymer Science \& Engineering, SungKyunKwan University, Suwon, Gyeonggi-do 440-146, South Korea.

Received: 24 January 2011 Accepted: 28 May 2011

Published: 28 May 2011

\section{References}

1. Kearney L: Molecular cytogenetics. Best Pract Res Clin Haematol 2001, 14:645-668.

2. Bauman JG, Wiegant J, Borst P, Van Duijn P: A new method for fluorescence microscopical localization of specific DNA sequences by in situ hybridization of fluorochromelabelled RNA. Exp Cell Res 1980, 128:485-490.

3. Hougaard DM, Hansen H, Larsson LI: Non-radioactive in situ hybridization for mRNA with emphasis on the use of oligodeoxynucleotide probes. Histochem Cell Biol 1997, 108:335-344.

4. Jeffrey M, Levsky, Singer Robert H: Fluorescence in situ hybridization: past, present and future. J Cell Sci 2003, 116:2833-2838.

5. Lien KY, Lee GB: Miniaturization of molecular biological techniques for gene assay. Analyst 2010, 135:1499-1518.

6. Boedicker JQ, Li L, Kline TR, Ismagilov RF: Detecting bacteria and determining their susceptibility to antibiotics by stochastic confinement in nanoliter droplets using plug-based microfluidics. Lab Chip 2008, 8:1265-1272.

7. Huang FC, Liao CS, Lee GB: An integrated microfluidic chip for DNA/RNA amplification electrophoresis separation and on line optical detection. Electrophoresis 2006, 27:3297-3305

8. Yamaguchi Y, Ogura D, Yamashita K, Miyazaki M, Nakamura H, Maeda H: A method for DNA detection in a microchannel: Fluid dynamics Phenomena and optimization of microchannel structure. Talanta 2006, 68:700-707.

9. Srinivasan V, Pamula VK, Fair RB: Droplet based microfluidic lab on a chip for glucose detection. Anal Chim Acta 2004, 507:145-150.

10. Yakovleva J, Davidsson R, Lobanova A, Bengtsson M, Eremin S, Laurell T, Emneus J: Microfluidic enzymes immunoassay using silicon microchip with immobilized antibodies and chemiluminescence detection. Anal Chem 2002, 74:2994-3004.

11. Yakovleva J, Davidsson R, Bengtsson M, Laurell T, Emneus J: Microfluidic enzyme immunosensors with immobilised protein $A$ and $G$ using chemiluminescence detection. Biosens Bioelectron 2003, 19:21-34.

12. Davidsson R, Boketoft A, Bristulf J, Kotarsky K, Olde B, Owman C, Bengtsson M, Laurell T, Emneus J: Developments towards a microfluidic system for long-term monitoring dynamic cellular events in immobilized human cells. Anal Chem 2004, 76:4715-4720

13. Hsu HY, Huang YY: RCA combined nanoparticle-based optical detection technique for protein microarray: a novel approach. Biosens Bioelectron 2004, 20:123-126.

14. McKendry R, Zhang J, Arntz Y, Strunz T, Henger M, Lang HP, Baller MK, Certa U, Meyer E, Guntherodt HJ, Gerber C: Multiple label-free biodetection and quantitative DNA-binding assays on a nanomechanical cantilever array. PNAS 2002, 99:9783-9788.

15. Laiwattanapaisal W, Yakovleva J, Bengtsson M, Laurell T, Wiyakrutta S, Meevootisom V, Chailapakul O, Emneus J: On-chip microfluidic systems for determination of L-glutamate based on enzymatic recycling of substrate. Biomicrofluidics 2009, 3:0141104-1, -0141104-12..

16. Neale MC, Kendler KS: Models of comorbidity for multifactorial disorders. Am J Hum Genet 1995, 57:935-953.

17. Cruts M, Hendriks L, Van Broeckhoven C: The presenilin genes: a new gene family involved in Alzheimer disease pathology. Hum Mol Genet 1996, 5:1449-1455
18. Blacker D, Tanzi RE: The genetics of Alzheimer disease: current status and future prospects. Arch Neurol 1998, 55:294-296.

19. Poewe W, Gauthier S, Aarsland D, Leverenz JB, Barone P, Weintraub D, Tolosa E, Dubois B: Diagnosis and management of Parkinson's disease dementia. Int J Clin Pract 2008, 62:1581-1587.

20. Berchtold NC, Cotman CW: Evolution in the conceptualization of dementia and Alzheimer's disease: Greco-Roman period to the 1960s. Neurobiol 1998, 19:173-189.

21. Ottman R: Gene-environment interaction and public health. Am J Hum Genet 1995, 56:821-823.

22. Pericak-Vance MA, Haines JA: Genetic susceptibility to Alzheimer disease. Trends Genet 1995, 11:504-508.

23. Sisodia SS: Series Introduction: Alzheimer's disease: perspectives for the new millennium. J Clin Invest 1999, 104:1169-1170.

24. Seppo H: Molecular genetics of Alzheimer's disease with special emphasis on presenilin, amyloid beta precursor protein and apolipoprotein E genes. PhD thesis University of Kuopio, Neurology Department; 1998

25. Singh S, Singh M, Gambhir IS: Nanotechnology for alzheimer's disease detection. Dig J Nanomater Bios 2008, 3:75-79.

26. Pellestor F, Paulasova P: The peptide nucleic acids (PNAs), powerful tools for molecular genetics and cytogenetics. Eur J Hum Genet 2004, 12:694-700.

27. Giesen U, Kleider W, Berding C, Geiger A, Orum H, Nielsen PE: A formula for thermal stability $(\mathrm{Tm})$ prediction of PNA/DNA duplexes. Nucleic Acids Res 1998, 26:5004-5006.

28. Egholm M, Buchardt O, Christensen L, Behrens C, Freier SM, Driver DA, Berg RH, Kim SK, Norden B, Nielsen PE: PNA hybridizes to complementary oligonucleotides obeying the Watson-Crick hydrogen bonding rules. Nature 1993, 365:556-568

29. Lansdorp PM, Verwoerd NP, Van De Rijke FM, Dragowska V, Little MT, Dirks RW, Raap AK, Tanke HJ: Heterogeneity in telomere length of human chromosomes. Hum Mol Genet 1996, 5:685-691.

30. Nielsen PE, Egholm M: An Introduction to Peptide Nucleic Acid. Curr Issues Mol Biol 1999, 1:89-104.

31. Zhang $Y$, Kim $\mathrm{H}$, Heller A: Enzyme-Amplified Amperometric Detection of 3000 Copies of DNA in a 10- $\mu \mathrm{L}$ Droplet at $0.5 \mathrm{fM}$ Concentration. Anal Chem 2003, 75:3267-3269.

32. Liu J, Tian S, Tiefenauer L, Nielsen PE, Knoll W: Simultaneously amplified electrochemical and surface plasmon resonce optical detection of DNA hybridization based on ferrocene-streptavidin conjugates. Anal Chem 2005, 77:2756-2761.

33. Beatty B, Mai S, Squire J: FISH: A Practical Approach Oxford University Press: 2002

34. Andreeff M, Pinkel D: Introduction to Fluorescence In Situ Hybridization: Principles and Clinical Applications Wiley-Liss Inc; 1999.

35. Bishop R: Applications of fluorescence in situ hybridization (FISH) in detecting genetic aberrations of medical significance. Biohorizons 2010, 3:85-95.

36. Gozzetti A, Le Beau MM: Fluorescence in situ hybridization: uses and limitations. Semin Hematol 2000, 37:320-333.

37. Sieben VJ, Debes Marun PM, Pilarski GV, Kaigala LM, Pilarski CJ: FISH and chips:Chromosomal analysis on microfluidic platforms. IET Nanobiotechnol 2007, 1:25-37.

38. Oberringer M, Englisch A, Heinz B, Goa H, Martin T, Hartmann U: Atomic force microscopy and scanning near-field optical microscopy studies on the characterization of human metaphase chromosomes. Eur Biophys $J$ 2003, 32:620-627.

39. Georganopoulou DG, Chang L, Nam JM, Thaxton CS, Mufson EJ, Klein WL, Mirkin CA: Nanoparticle-based detection in cerebral spinal fluid of a soluble pathogenic biomarker for Alzheimer's disease. Proc Natl Acad Sci 2005, 102:2273-2276.

40. lourov IY, Vorsanova SG, Liehr T, Yurov YB: Aneuploidy in the normal Alzheimer's disease and ataxia-telangiectasia brain: Differential expression and pathological meaning. Neurobiol Dis 2009, 34:212-220.

41. Yang Y, Geldmacher DS, Herrup K: DNA replication precedes neuronal cell death in Alzheimrs disease. J Neurosci 2001, 21:2661-2668.

42. Mosch B, Morawski M, Mittag A, Lenz D, Tarnok A, Arendt T: Aneuploidy and DNA replication in the normal human brain and Alzheimer's disease. J Neurosci 2007, 27:6859-6867. 
43. Li J, Xu M, Zhou H, Ma J, Potter H: Alzheimer presenilins in the nuclear membrane, interphase kinetochores, and centrosomes suggest a role in chromosome segregation. Cell 1997, 90:917-927.

44. Geller LN, Potter H: Chromosome missegregation and trisomy 21 mosaicism in Alzheimer's disease. Neurobiol Dis 1999, 6:167-179.

45. Migliore L, Botto N, Scapato R, Petrozzi L, Cipriani G, Bonucceli U: Preferential occurrence of chromosome 21 malsegregation in peripheral blood lymphocytes of Alzheimer disease patients. Cytogenet Cell Genet 1999, 87:41-46.

46. Yurov YB, Soloviev IV, Vorsanova SG, Marcais B, Roizes G, Lewis R: High resolution fluorescence in situ hybridization using cyanine and fluorescein dyes: ultra-rapid chromosome detection by directly fluorescently labeled alphoid DNA probes. Hum Genet 1996, 97:390-398.

47. Yurov YB, lourov IY, Monakhov W, Soloviev IV, Vostrikov VM, Vorsanova SG: The variation of aneuploidy frequency in the developing and adult human brain revealed by an interphase FISH study. J Histochem Cytochem 2005, 53:385-390.

48. Vorsanova SG, Kolotii AD, lourov IY, Monakhov W, Kirillova EA, Soloviev IV, Yurov YB: Evidence for high frequency of chromosomal mosaicism in spontaneous abortions revealed by interphase FISH analysis. $J$ Histochem Cytochem 2005, 53:375-380.

49. Liehr T, Heller A, Starke H, Rubtsov N, Trifonov V, Mrasek K, Weise A, Kuechler A, Claussen U: Microdissection based high resolution multicolor banding for all 24 human chromosomes. Int J Mol Med 2002, 9:335-339.

50. Iourov IY, Liehr T, Vorsanova SG, Kolotii AD, Yurov YB: Visualization of interphase chromosomes in postmitotic cells of the human brain by multicolor banding. Chromosome Res 2006, 14:223-229.

51. lourov IY, Liehr T, Vorsanova SG, Yurov YB: Interphase chromosomespecific multicolor banding (ICS-MCB): A new tool for analysis of interphase chromosomes in their integrity. Biomol Eng 2007, 24:415-417.

52. Corder EH, Saunders AM, Strittmatter WJ, Schmechel DE, Gaskell PC, Small GW, Roses AD, Haines JL, Pericak Vance MA: Gene dosage of apolipoprotein E type 4 allele and the risk of Alzheimer's disease in late onset families. Science 1993, 261:921-923.

53. St George-Hyslop PH, McLachlan DC, Tsuda T, Rogaev El, Karlinski H, Lippa CF, Pollen D: Alzheimer's disease and possible gene interaction. Science 1994, 263:537.

54. Takano T, Yamanouchi Y, Sahara N, Shirasawa T, Mori H: Assignment of Alzheimer's presenilin-1 (PS-1) gene to $14 q 24.3$ by fluorescence in situ hybridization. Neuroscience Letters 1996, 214:69-71.

55. Takata M, Nakashima M, Takehara T, Baba H, Machida K, Akitake Y, Ono K, Hosokawa M, Takahashi M: Detection of amyloid protein in the urine of Alzheimer's disease patients and healthy individuals. Neurosci Lett 2008, 435:126-130.

56. Selkoe D: Normal and abnormal biology of the ß-amyloid precursor protein. Annu Rev Neurosci 1994, 17:489-517.

57. Anderson N, Vanmechelen E, Van de Voorde A, Davidsson P, Hesse C, Tarvonen S, Raiha I, Sourander L, Winblad B, Blennow K: Cerebrospinal fluid tau protein as a biochemical marker for Alzheimer's disease: a community based follow up study. J Neurol Neurosurg PS 1998, 64:298-305.

58. Vanmechelen $E$, Vanderstichele $H$, Davidsson P, Van Kerschaver E, Van Der Perre B, Sjogren M, Andreasen N, Blennow K: Quantification of tau phosphorylated at threonine 181 in human cerebrospinal fluid: a sandwich ELISA with a synthetic phosphopeptide for standardization. Neurosci Lett 2000, 285:49-52.

59. Kamruecha W, Chansirikarnjana S, Nimkulrat E, Udommongkol C, Wongmek W, Thangnipon W: Rapid detection of Apolipoprotein E genotypes in alzheimer's disease using polymerase chain reaction-single strand conformation polymorphism. Se Asian j Trop Med 2006, 37:793-797.

60. Bermejo-Pareja F, Antequera, Vargas T, Molina JA, Carro E: Saliva levels of Abeta1-42 as potential biomarker of Alzheimer's disease: a pilot study. BMC Neurol 2010, 10:108.

61. Lenkkeri U, Kestila M, Lamerdin J, Adamson A, Olsen A, Tryggvason K: Structue of the human amyloid precursor like protein gene APLP 1 at 19q13.1. Hum genet 1998, 102:192-196.

62. Bush Al, Martins RN, Rumble B, Moir R, Fuller S, Milward E, Currie J, Amesn D, Weidemannll A, Fischer P, Multhaup G, Beyreuther K, Masters CL: The Amyloid Precursor Protein of Alzheimer's Disease Is Released by Human Platelets. J Biol Chem 1990, 265:15977-15963.

63. Cruts M, Van Duijn CM, Backhovens $H$, Van den Broeck M, Wehnert A, Serneels S, Sherrington R, Hutton M, Hardy J, St George-Hyslop PH,
Hofman A, Van Broeckhoven C: Estimation of the Genetic Contribution of Presenilin-1 and -2 Mutations in a Population-Based Study of Presenile Alzheimer Disease. Hum Mol Genet 1998, 7:43-51.

64. Nemeroff CB, Bissette G, Akil H, Fink M: Neuropeptide concentrations in the cerebrospinal fluid of depressed patients treated with electroconvulsive therapy. Corticotrophin-releasing factor, betaendorphin and somatostatin. Br J Psychiatry 1991, 158:59-63.

65. Durlach J: Magnesium depletion and pathogenesis of Alzheimer's disease. Magnesium Research 1990, 3:217-218.

66. Spremo-Potparevic B, Zivkivic L, Djelic N, Bajic V: Analysis of premature centromere division (PCD) of the $\mathrm{X}$ chromosome in Alzheimer patients trough the cell cycle. Exp Gerontol 2004, 39:849-854.

67. Zivkovic L, Spremo-Potparevic B, Djelic N, Bajic V: Analysis of premature centromere division (PCD) of the chromosome 18 in peripheral blood lymphocytes in Alzheimer disease patients. Mech Ageing Dev 2006, 127:892-896.

68. Migliore L, Testa A, Scarpato R, Pavese N, Petrozzi L, Bonuccelli U: Spontaneous and induced aneuploidy in peripheral blood lymphocytes of patients with Alzheimer's disease. Hum Genet 1997, 101:299-305.

69. Sieben VJ, Debes-Marun CS, Pilarski LM, Backhouse CJ: An integrated microfluidic chip for chromosome enumeration using fluorescence in situ hybridization. Lab Chip 2008, 8:2151-2156.

70. Lee DS, Lee JH, Min HC, Kim TY, Oh BR, Kim HY, Lee JY, Lee CK, Chun HG, Kim HC: Application of high throughput cell array technology to FISH: investigation of the role of deletion of p16 gene in leukemias. $J$ Biotechnol 2007, 127:355-360.

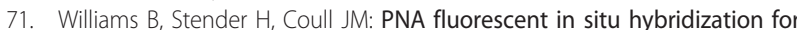
rapid microbiology and cytogenetic analysis. In Peptide nucleic acids; methods and protocols. Volume 208. Edited by: Nielsen PE. Totowa, New York: Humana Press Inc; 2002:181-193

72. Gaylord BS, Massie MR, Feinstein SC, Bazan GC: SNP detection using peptide nucleic acid probes and conjugated polymers: Applications in neurodegenerative disease identification. PNAS 2005, 102:34-39.

73. Clark LN, Poorkaj P, Wszoleke Z, Geschwind DH, Nasreddine ZS, Miller B, Li D, Payami H, Awert F, Markopoulou K, Andreadis A, DSouza I, Lee VM, Reed L, Trojanowski JQ, Zhukarevak V, Bird T, schellenberg G, Wilhelmsen KC: Pathogenic implications of mutations in the tau gene in Pallido-ponto-nigral degeneration and related neurodegenerative Disorders linked to chromosome 17. P Natl Acad Sci USA 1998, 95:13103-13107.

74. Takano T, Sahara N, Yamanouchi Y, Mori H: Assignment of Alzheimer's presenilin-2 (PS-2) gene to 1q42.1 by fluorescence in situ hybridization. Neurosci Lett 1997, 221:205-207.

75. Gross PG, Kartalov EP, Scherer A, Weiner LP: Applications of microfluidics for neuronal studies. J Neurol Sci 2007, 252:135-143.

76. Weiler J, Gausepohl H, Hauser N, Jensen ON, Hoheisel JD: Hybridisation based DNA screening on peptide nucleic acid (PNA) oligomer arrays. Nucleic Acids Res 1997, 25:2792-2799.

77. Matysiak S, Reuthner F, Hoheisel JD: Automating parallel peptide synthesis for the production of PNA library arrays. Biotechniques 2001, 31:896-898.

78. Hiepa HM, Endo T, Kim DK, Tamiya E: Nanostructure and molecular interface for biosensing devices. Proc SPIE-Int Soc Opt Eng 2007, 6768:6768-1, -6781-11..

79. Huang $Y$, Rubinsky B: Flow-through micro-electroporation chip for high efficiency single-cell genetic manipulation. Sens Actuators A Phys 2003, 104:205-212

80. Khine M, Lau A, lonescu-Zanetti C, Seo J, Lee LP: A single cell electroporation chip. Lab Chip 2005, 5:38-43.

81. Hong JW, Studer V, Hang G, Anderson WF, Quake SR: A nanoliter- scale nucleic acid processor with parallel architecture. Nat Biotechnol 2004, 22:435-439.

82. Beebe DJ, Mensing GA, Walker GM: Physics and applications of microfluidics in biology. Annu Rev of Biomed Eng 2002, 4:261-286.

83. De mello AJ: Control and detection of chemical reactions in microfluidic systems. Nature 2006, 442:394-402.

84. El-Ali J, Sorger PK, Jensen KF: Cells on chips. Nature 2006, 442:403-411.

85. Psaltis D, Quake SR, Yang CH: Developing optofluidic technology through the fusion of microfluidics and optics. Nature 2006, 442:381-386.

86. Stone HA, Stroock AD, Ajdari A: Engineering flows in small devices microfluidics toward a lab-on-a-chip. Annu Rev Fluid Mech 2004, 36:381-411. 
87. Whitesides GM: The origins and the future of microfluidics. Nature 2006, 442:368-373.

88. Yager P, Edwards T, Fu E, Helton K, Nelson K, Tam MR, Weigl BH: Microfluidic diagnostic technologies for global public health. Nature 2006, 442:412-418

89. Zengerle R: Microfludics. In proceedings Micromechanics Europe 1998 Ulvik, Norvay; 1998, 111-122.

90. Rivet C, Lee H, Hirsch A, Hamilton S, Lu H: Microfluidics for medical diagnostics and biosensors. Chem Eng SCi.

91. Pan YJ, Lin JJ, Luo WJ, Yang RJ: Sample flow switching techniques on microfluidic chips. Biosens Bioelectron 2006, 21:1644-1648.

92. Blankenstein G, Larsen UD: Modular concept of a laboratory on a chip for chemical and biochemical analysis. Biosens Bioelectron 1998, 13:427-438.

93. Chin CD, Linder V, Sia SK: Lab-on-a-chip devices for global health: past studies and future opportunities. Lab Chip 2007, 7:41-57.

94. Martinez AW, Phillips ST, Butte MJ, Whitesides GM: Patterned paper as a platform for inexpensive, low-volume, portable bioassays. Angew Chem Int Ed Engl 2007, 46:1318-1320.

95. Derda R, Laromine A, Mammotto A, Tang SKY, Mammoto T, Ingber DE, Whitesides GM: Paper-supported 3D cell culture for tissue-based bioassays. P Natl Acad Sci USA 2009, 106:18457-18462.

96. Cui X, Lee LM, Heng X, Zhong W, Sternberg PW, Psaltis D, Yang C: Lensless high-resolution on-chip optofluidic microscopes for Caenorhabditis elegans and cell imaging. P Natl Acad Sci USA 2008, 105:10670-10675.

97. Hatakeyama K, Tanaka T, Sawaguchi M, Iwadate A, Mizutani Y, Sasaki K, Tateishi N, Matsunaga T: Microfluidic device using chemiluminescence and a DNA-arrayed thin film transistor photosensor for single nucleotide polymorphism genotyping of PCR amplicons from whole blood. Lab Chip 2009, 9:1052-1058.

98. Park T, Lee S, Seong GH, Choo J, Lee EK, Kim YS, Ji WH, Hwang SY, Gweond DG, Lee S: Highly sensitive signal detection of duplex dyelabelled DNAoligonucleotides in a PDMS microfluidic chip: confocal surface-enhanced Raman spectroscopic study. Lab Chip 2005, 5:437-442.

99. Sieben VJ, Debes-Marun CS, Pilarski LM, Backhouse CJ: An integrated microfluidic fish chip: enumerating chromosomes on a cell-by-cell basis in less than 1 hour. 2008, 531-533, In proceedings of the Twelfth International Conference on Miniaturized Systems for Chemistry and Life Sciences, 12-16 October 2008, San Diego, California, USA,

100. Li S, Goluch E, Liu C, Szegedi S, Shaikh K, Ahmed F, Hu A, Zhao S: Gold Nanoparticle-Based Biodetection for Chip-Based Portable Diagnosis Systems. JALA 2010, 15:107-113.

101. Goluch ED, Nam JM, Georganopoulou DG, ChiesI TN, Shaikh KA, Ryu KS, Barron AE, Mirkin CA, Liu C: A bio-barcode assay for on-chip attomolarsensitivity protein detection. Lab chip 2006, 6:1293-1299.

102. Zhang J, Lang HP, Huber F, Bietsch A, Grange W, Certa U, McKendry R, Guntgerodt HJ, Hegner M, Gerber C: Rapid and label-free nanomechanical detection of biomarker transcripts in human RNA. Nat Nanotechnol 2006, 1:214-220

103. Thaxton CS, Hill HD, Georganopoulou DG, Stoeva SI, Mirkin CA: A Bio-BarCode Assay Based upon Dithiothreitol-Induced Oligonucleotide Release. Anal Chem 2005, 77:8174-8178.

104. Fan R, Vermesh O, Srivastava A, Yen BK, Qin L, Ahmad H, Kwong GA, Liu CC, Gould J, Hood L, Heath JR: Integrated barcode chips for rapid multiplexed analysis of proteins in microliter quantities of blood. Nat Biotechnology 2008, 26:1373-1378.

105. Lee DS, Lee JH, Chung HC Min, Kim TY, Oh BR, Kim HY, Lee JY, Lee CK, Chun HG, Kim HC: Application of high throughput cell array technology to FISH: Investigation of the role of deletion of p16 gene in leukemias. J Biotechnol 2007, 127:355-360.

106. Verpoorte E: Microfluidic chips for clinical and forensic analysis. Electrophoresis 2002, 23:677-712.

107. Kong J, Franklin NR, Zhou C, Chapline MG, Peng S, Cho K, Dai H: Nanotube molecular wires as chemical sensors. Science 2000, 287:622-625.

108. Dekker C: Solid-state nanopores. Nat Nanotechnol 2007, 2:209-215.

109. Huang Y, Mather EL, Bell JL, Madou M: MEMS-based sample preparation for molecular diagnostics. Anal Bioanal Chem 2002, 372:49-65.

110. De Mello AJ, Beard N: Dealing with 'real' samples: sample pre-treatment in microfluidic systems. Lab Chip 2003, 3:11N-19N.

111. Pawliszyn J: Sample preparation quo-vadis. Anal Chem 2003, 75:2543-2558.

112. Kim J, Johnson M, Hill P, Gale BK: Microfluidic sample preparation: cell lysis and nucleic acid purification. Integr Biol 2009, 1:574-586.
113. Takamatsu H, Takeya R, Naito S, Sumimoto H: On the Mechanism of Cell Lysis by Deformation. J Biomech 2005, 38:117-124.

114. Kim YC, Kang JH, Park SJ, Yoon ES, Park JK: Microfluidic biomechanical device for compressive cell stimulation and lysis. Sensor Actuat B-chem 2007, 128:108-116

115. Marentis TC, Kusler B, Yaralioglu GG, Liu S, Haeggstrom EO, Khuri-Yakub BT: Microfluidic sonicator for real-time disruption of eukaryotic cells and bacterial spores for DNA analayis. Ultrasound Med Biol 2005, 31:1265-1277.

116. Taylor MT, Belgrader P, Furman BJ, Pourahmadi F, Kovacs GT, Northrup MA: Lysing Bacterial Spores by Sonication through a Flexible Interface in a Microfluidic System. Anal Chem 2001, 73:492-496.

117. Rau KR, Quinto-Su PA, Hellman AN, Venugopalan V: Pulsed laser microbeam-induced cell lysis: time-resolved imaging and analysis of hydrodynamic effects. Biophys J 2006, 91:317-329.

118. Frank Richard A, Galasko D, Hampel H, Hardy J, De Leon MJ, Mehta PD, Rogers J, Siemers E, Trojanowski JQ: Biological markers for therapeutic trials in Alzheimer's disease-Proceedings of the biological markers working group; NIA initiative on neuroimaging in Alzheimer's disease. Neurobiol Aging 2003, 24:521-536.

119. Sennvik K, Fastbom J, Blomberg M, Wahlund LO, Winblad B, Benedikz E: Levels of alpha- and beta-secretase cleaved amyloid precursor protein in the cerebrospinal fluid of Alzheimer's disease patients. Neurosci Lett 2000, 278:169-172

120. Sambrook J, Russell DW: Molecular Cloning: A Laboratory Manual Cold Spring Harbor Labourator press; 2001.

121. Vinograd J, Lebowitz J: Physical and topological properties of circular DNA. Gen Physiol 1966, 49:103-125.

122. Yust I, Frisch B, Goldsher N: Simultaneous detection of two mechanisms of immune destruction of penicillin-treated human red blood cells. Am J Hematol 1982, 13:53-62.

123. Pang Z, Al-Mahrouki A, Berezovski M, Krylov SN: Selection of surfactants for cell lysis in chemical cytometry to study protein-DNA interactions. Electrophoresis 2006, 27:1489-1494.

124. Von Hippel PH, Wong KY: Neutral salts: The generality of their effects on the stability of macromolecular conformations. Science 1964, 145:577-580.

125. Boom R, Sol CJ, Salimans MM, Jansen CL, Wertheim-van Dillen PM, Van der Noordaa J: Rapid and simple method for purification of nucleic acids. J Clin Microbiol 1990, 28:495-503.

126. Chirgwin JM, Przybyla AE, MacDonald RJ, Rutter WJ: Isolation of biologically active ribonucleic acid from sources enriched in ribonuclease. Biochemistry 1979, 18:5294-5299.

127. Tamaoka A, Sawamura N, Fukushima T, Shoji S, Matsubara E, Shoji M, Hirai S, Furiya $Y$, Endoh R, Mori H: Amyloid beta protein 42(43) in cerebrospinal fluid of patients with Alzheimer's disease. J Neurol Sci 1997, 148:41-45

128. Cheng J, Sheldon EL, Wu L, Uribe A, Gerrue LO, Carrino J, Heller MJ, Connell JPO: Preparation and Hybridization Analysis of DNA/RNA from E. coli on Microfabricated Bioelectronic Chips. Nat Biotechnol 1998, 16:541-546.

129. Lu H, Schmidt MA, Jensen KF: Microfluidic Electroporation Device for Controlled Cell Lysis. Lab Chip 2005, 5:23-29.

130. Lee SW, Tai YC: A micro cell lysis device. Sensor Actuat A-phys 1999, 73:74-79.

131. Tian $\mathrm{H}$, Huhmer AFR, Landers JP: Evaluation of silica resins for the direct and efficient extraction of DNA from complex biological matrics in a miniaturized format. Anal Biochem 2000, 283:175-191.

132. Breadmore MC, Wolfe KA, Arcibal IG, Leung WK, Dickson D, Giordano BC, Power ME, Ferrance JP, Feldman SH, Norris PM, Landers JP: Microchipbased purification of DNA from biological samples. Anal Chem 2003, 75:1880-1886.

133. Wolfe KA, Breadmore MC, Ferance JP, Power ME, Conroy JF, Norris PM, Landers JP: Toward a Microchip-based Solid-Phase Extraction Method for Isolation of Nucleic Acids. Electrophoresis 2002, 23:727-733.

134. Wu Q, Bienvenue JM, Hassan BJ, Kwok YC, Giordano BC, Norris PM, Landers JP, Ferrance JP: A Microchip-based Macroporous Silica Sol-gel Monolith for Efficient Isolation of DNA From Clinical Samples. Anal Chem 2006, 78:5704-5710.

135. Goedert M: Tau protein and the neurofibrillary pathology of Alzheimer's disease. TINS 1993, 16:460-465.

136. Hampel H, Teipel SJ, Faltraco F, Brettschneider S, Goernitz A, Buerger K, Moeller $\mathrm{HJ}$ : Molecular neurobiology of Alzheimer's disease and related 
disorders.Edited by: Takeda M, Tanaka T, Cacabelos R. Tokio: Karger Publishers; 2003.

137. Vestergaard M, Kerman K, Kim DK, Ha MH, Tamiya E: Detection of Alzheimer's tau protein using localised surface plasmon resonancebased immunochip. Talanta 2008, 74:1038-1042.

138. Mahley RW: Apolipoprotein E: cholesterol transport protein with expanding role in cell biology. Science1988 240:622-630.

139. Emi M, Wu LL, Robertson MA, Myers RL, Hegele RA, Williams RR, White R, Lalouel JM: Genotyping and sequence analysis of apolipoprotein E isoforms. Genomics 1988, 3:373-379.

140. Ji HM, Samper V, Chen Y, Hui WC, Lye HJ, Mustafa FB, Lee AC, Cong L, Heng CK, Lim TM: DNA purification silicon chip. Sensor Actuat A-Phys 2007, 139:139-144.

141. Kim J, Johnson M, Hill P, Sonkul R, Kimand J, Gale BK: 2009, Integreated Microfludic RNA extraction system Proceedings of the 5th Conference Microtechnologies in Medicine and Biology, Quebec, Canada.

142. Cao W, Easley CJ, Ferrance JP, Landers JP: Chitosan as a polymer for pHinduced DNA capture in a totally aqueous system. Anal Chem 2006, 78:7222-7228.

143. Lien KY, Liu CJ, Kuo PL, Lee GB: Microfluidic system for detection of athalassemia -1 detection using saliva samples. Anal Chem 2009, 81:4502-4509.

144. Park SJ, Taton TA, Mirkin CA: Array-based electrical detection of DNA with nanoparticle probes. Science 2002, 295:1503-1506.

145. Dixon MC: Quartz crystal microbalance with dissipation monitoring: enabling real-time characterization of biological materials and their interactions. J Biomol Tech 2008, 19:151-158.

146. Fritz J: Cantilever biosensors. Analyst 2008, 133:855-863.

147. Yun YH, Eteshola E, Bhattacharya A, Dong Z, Shim JS, Conforti L, Kim D, Schulz MJ, Ahn CH, Watts N: Tiny Medicine: Nanomaterial-Based Biosensors. Sensors 2009, 9:9275-9299.

148. Gerard E, Guyot F, Philippot P, Garcia PL: Fluorescence in situ hybridisation coupled to ultra small immunogold detection to identify prokaryotic cells using transmission and scanning electron microscopy. J Microbiol Meth 2005, 63:20-28.

149. Binder M, Tourmente S, Roth J, Renaud M, Gehring WJ: In Situ Hybridization at the Electron Microscope Level: Localization of Transcripts on Ultrathin Sections of Lowicryl K4M-embedded Tissue Using Biotinylated Probes and Protein A-Gold Complexes. J Cell Biol 1986, 102:1646-1653.

150. Kewal K, Jain T: Review Nanotechnology in clinical laboratory diagnostics. Clinica Chimica Acta 2005, 358:37-54.

151. Bailey RC, Kwong GA, Radu CG, Witte ON, Heath JR: DNA-encoded antibody libraries: a unified platform for multiplexed cell sorting and detection of genes and proteins. J Am Chem Soc 2007, 129:1959-1967.

152. Wang J, Li J, Baca AJ, Hu J, Zhou F, Yan W, Pang DW: Amplified Voltammetric Detection of DNA Hybridization via Oxidation of Ferrocene Caps on Gold Nanoparticle/Streptavidin Conjugates. Anal Chem 2003, 75:3941-3945.

153. Li YT, Liu HS, Lin HP, Chen SH: Gold nanoparticles for microfluidics-based biosensing of PCR products by hybridization-induced fluorescence quenching. Electrophoresis 2005, 26:4743-4750.

154. Kim J, Junkin M, Kim DH, Kwon S, Shin YS, Wong PK, Gale BK: Applications, techniques, and microfluidic interfacing for nanoscale biosensing. Microfluid Nanofluid 2009, 7:149-167.

155. Wang Y, Xu C, Li J, Hsing IM, Chan M: A CMOS active pixel sensor based DNA micro-array with nano-metallic particles detection protocol. Solid State Electron 2005, 49:1933-1936.

156. Breslauer DN, Maamari RN, Switz NA, Lam WA, Fletcher DA: Mobile phone based clinical microscopy for global health applications. PLOS ONE 2009, 4:e6320.

157. Martinez AW, Phillips ST, Carrilho E, Thomas SW, Sindi H, Whitesides GM: Simple telemedicine for developing regions: camera phones and paperbased microfluidic devices for real-time, off-site diagnosis. Anal chem 2008, 80:3699-3707.

doi:10.1186/1423-0127-18-33

Cite this article as: Devadhasan et al: Fish-on-a-chip: a sensitive detection microfluidic system for alzheimer's disease. Journal of Biomedical Science 2011 18:33.

\section{Submit your next manuscript to BioMed Central and take full advantage of:}

- Convenient online submission

- Thorough peer review

- No space constraints or color figure charges

- Immediate publication on acceptance

- Inclusion in PubMed, CAS, Scopus and Google Scholar

- Research which is freely available for redistribution

Submit your manuscript at www.biomedcentral.com/submit
Biomed Central 